\title{
The Role of Local Precipitation Models in Designing Rainwater Drainage Systems in Urban Areas: a Case Study in Krakow, Poland
}

\author{
Andrzej Wałęga*, Grzegorz Kaczor, Błażej Stęplewski \\ Department of Sanitary Engineering and Water Management, University of Agriculture in Kraków, \\ Mickiewicza 24-28, Kraków 30-050, Poland
}

Received: 27 November 2015

Accepted: 29 April 2016

\begin{abstract}
Our paper analyzed the hydraulic aspects of a rainwater-collecting pipe operation in the conditions of rainfall events calculated using two different models. Model I is recommended for use across the entire country, while model II has a more local character. The dimensions of the collecting pipe were determined in two variants, depending on the employed rainfall model. Finally, the hydraulic capacity of the channel was verified under different conditions of rainwater volume. The investigated area is located in the southeastern part of Krakow, a city in southern Poland. The study covered a catchment area of $9,000 \mathrm{~m}^{2}$. The calculation outcomes indicate that the design rainfall intensity determined in model II was higher for the time interval recommended for the drainage system design than in model I. The numerical calculations performed in the storm water management model (SWMM) program, showed that the collecting pipe design based on rainfall intensity from model II was capable of intercepting the design runoff volume, offering storage volume over a substantial length of pipe.
\end{abstract}

Keywords: rainfall-runoff model, SWMM program, design rainfall, urban areas

\section{Introduction}

The urbanization process tends to substitute natural vegetation with impervious surfaces, thus reducing infiltration. It also tends to eliminate natural retention ponds and to rectify river courses, thus greatly interfering with superficial flows $[1,2]$. Therefore, floods in urban areas are characterized by greater runoff volumes and flow velocities, resulting in higher flow peaks and water stages

*e-mail: a.walega@ur.krakow.pl
[3]. Inflow of stormwater to the sewer system during heavy rainfall can have an adverse effect on most sewage treatment plant technological processes [4]. This way, urbanization aggravates floods and, as can be seen in city development, it was not always possible to accomplish urban growth with adequate infrastructure - especially in developing and poor countries. Even in wealthy countries, urban growth stresses the existing infrastructure [5].

Urban floods are slightly different from those occurring in natural catchments. Their influence range is limited and they result from short, but very intense 
rainfall of a torrential character. Local floods (often called flash floods) do not exert a significant impact on the conditions in larger rivers [6-7]. O'Driscoll, Clinton, Jefferson, Manda, and Mcmillan [2] have reported that peak flow in urbanized areas may by $400 \%$ higher than pre-development catchment. The research carried out by Przybyła, Bykowski, Mrozik, and Napierała [8] in the catchment area of the Skórzanka watercourse has shown that intensive built-up areas contribute to the acceleration of runoff from the catchment area and increase the maximum flows in local watercourses, resulting in hydraulic overload of the existing rainwater drainage system. In addition, with a large share of hardened surface in the catchment, as much as $80 \%$ of rainwater is quickly collected and discharged by means of a rainwater drainage system to a network of ditches often unsuitable for such large flows.

Different properties of rainfall, dissimilar dynamics of runoff formation in the urban catchments, and the range and influence of urban flood events require that specialists on the design and expansion of the rainwater drainage systems use appropriate methods and input data specific to the urban catchments. Thus flood control is one of the major issues with which urban planners must deal today. Additionally, the lack of planning frequently worsens this situation. According to Mrozik, Przybyła, and Pyszny [9], more and more noticeable is the lack of law on metropolitan areas. Moreover, the same Authors have described that only in several percent of cases may we talk of the establishment of spatial order for a certain greater functionally coherent area. Many times, the absence of systemic design tools capable of representing the problem in an integrated approach leads to a decision process in which local solutions may be inadequate for the whole system needs. An important tool to be considered is mathematical modeling of hydrologic and hydraulic processes [10-13].

Spatial and temporal variability of extreme rainfall, plus its interactions with heterogeneous land cover and drainage networks, is a crucial driver of flood response, especially in urban settings where flow path lengths are short, runoff velocities are high, and the spatial distribution of land use and hydrologic infrastructure is highly heterogeneous [1416]. Rainfall intensity, frequency, and duration are the basic data necessary to correctly estimate runoff amount in a catchment [17]. This is particularly important while using hydrological and hydrodynamic models sensitive to changes in the input parameter values [18-19]. The impact of rainfall errors on predicted flow has been highlighted by many authors, including Kavetski, Kuczera, and Franks [20], Bárdossy and Das [21], and Moulin, Gaume, and Obled [22].

Rainfall frequency, which is necessary information when designing a sewer system, can be determined by statistical methods, approximating the observed precipitation data sequences with an adopted distribution function. Commonly used functions of rainfall distribution include Fisher-Tippett type $\mathrm{I}_{\max }$ and III $_{\text {min }}$, lognormal, Pearson's type III, generalized extreme value (GEV), or general logistics distribution [23-29]. Using direct methods (i.e., methods based on observed data), it is possible only in the case of long measurement series. Another solution is taking advantage of radar observations to reconstruct the sequences of rainfall characteristics, and then using them to determine intensity-duration-frequency (IDF) curves that also take into account the spatial variability of a rainfall field [30]. Sometimes a designer cannot use the existing data on the rainfall frequency. This usually happens with data describing short-term rains. Therefore, the designers commonly use local models to describe the properties of design rainfalls [31-34].

The rules for drainage sizing, developed in Poland in the 1950s and 1960s and well established in the national literature, are based on a physical model by Błaszczyk and have been increasingly criticized as inaccurate. This model, commonly used for the design of sewer systems, significantly underestimates the design rainfall intensity, thus leading to too small diameter of sewer channels and size of network objects [24]. An additional difficulty faced by the designers of drainage systems is often a lack of access to reliable and comprehensive rainfall databases. This problem is also present in the Krakow metropolitan area. The application of inappropriate methods for determining the IDF curves resulted in insufficient capacity of the designed and implemented rainwater channels, which are too narrow to collect the actual volume of rainwater discharge. Consequently, torrential rainfalls cause overflowing of the drainage system and water discharge through sewage sumps and manholes, with consequent flooding of basements, adjacent areas, and underground infrastructure of the city. For example, the flood of 2010 (the largest flood in Krakow since 1813), caused drainage flooding of 39 streets due to hydraulic overloading of the rainwater drainage network [35].

Studies conducted by Kotowski [31] in Wrocław (western Poland) shown that the use of local precipitation models significantly reduced the risk of water overflowing from the drainage system. Accurate determination of design flows also brings financial benefits, allowing for the construction of properly sized drainage pipes and network objects.

It has been shown that the development of local precipitation models for design purposes is very important for many reasons. A commonly employed approach to this topic is regional frequency analysis [28, 36-37]. The quality of the input data (in this case rainfall properties) is crucial for modeling a catchment runoff and obtaining correct results of a simulation [38]. The impact of input data uncertainties on urban drainage models is largely unknown. According to Zawilski and Brzezinska [39], using a network of pluviometer stations enables more accurate assessment of the frequency and volume of rainwater overflow from sewers than using data from a single station. This is particularly important in catchments with an area exceeding 200 hectares.

The aim of this study was to determine the suitability of local precipitation models based on Fisher-Tippett distribution to determine correct design parameters of a 
drainage system, and therefore to limit the frequency of rainwater overflow from a drainage system. The study was conducted in three stages. The first stage involved a comparison of the course of IDF curves, based on the widely used (in Poland) Błaszczyk's physical model and on the local precipitation model employing the Fisher-Tippett distribution of $I_{\max }$ type. At the second stage, the drainage system was sized based on resulting IDF rainfall curves, and at stage three the performance of the drainage pipes was verified using numerical modeling.

\section{Catchment Description}

The drainage network we investigated is in southeastern Krakow, a city in southern Poland. Currently, the catchment area is subject to intense anthropogenic transformations associated with modernization of the transportation system, housing development, and expansion of the storm and sewer drainage system. The study covered the catchment (Fig. 1) with a total area of $9,000 \mathrm{~m}^{2}$. This area is currently undeveloped, flat for the most part and only slightly sloping in the northern corner. Coordinates are close to $216.00 \mathrm{~m}$ above sea level. The substrate to a depth of $1.70 \mathrm{~m}$ is composed of non-cohesive soils (sands and gravels), and Miocene clays in deeper layers. The area under consideration is intended for construction of an asphalt road and multi-family residential and service buildings with underground garages. According to data received from the designer of the investment under consideration, the method for developing the land which is the basis for calculations presented are as follows: 0.39 ha tight roofs, 0.23 ha asphalt roads, 0.12 ha cobbled pavement, and 0.16 ha undeveloped land. The total catchment area

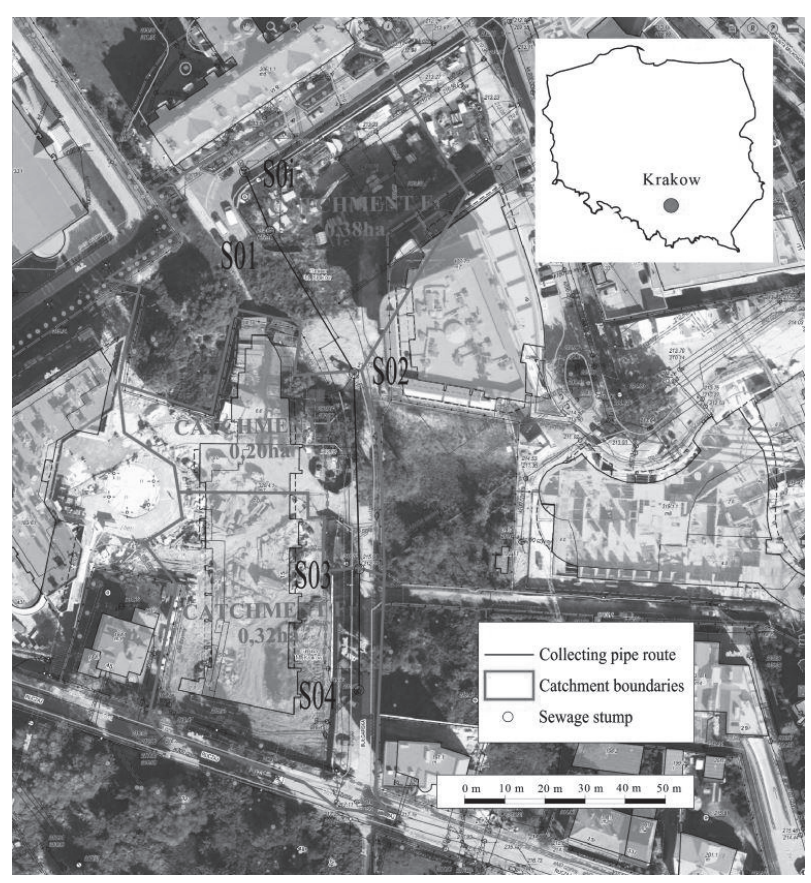

Fig. 1. Boundaries of the analyzed catchment. and partial catchments were determined based on height system prevailing in the area concerned, and the location of inflows to the collector from individual parts of the land being drained. The local spatial development plan for the area of the investment under consideration has not been prepared. This investment was implemented on the basis of a decision on land development and management conditions issued by the Krakow City Office.

In terms of hydrogeological conditions, groundwater (discontinuous, unconfined water table) is present in the sands at a depth of $2.4 \mathrm{~m}$ below ground level. The water level is highly dependent on weather conditions and subject to significant fluctuations. Gravitational seepage water occurs within cohesive soils at a depth of 1.0 to $1.7 \mathrm{~m}$ below ground level. In periods of increased rainfall or snowmelt, groundwater can occur within non-cohesive soils located directly below embankments, and water seepage can occur throughout the area.

According to the local development plan, a bituminous pavement road with a drainage system will be constructed in the area. Residential development is also planned.

\section{Material and Methods}

Our study procedure was divided into three stages:

1. Determining rainfall properties.

2. Sizing the drainage system based on rainfall intensity determined at Stage I and target area development.

3. Verification of the parameters of the designed sewage system based on numerical modeling.

Rainfall properties (used later on for sizing the area drainage system) were established using two models.

\section{Model I}

This model is recommended for the assessment of rainfall intensity in Poland. The intensity of design rainfall is calculated based on a formula developed by Błaszczyk, Roman, and Stamatello [40]:

$$
q=\frac{6,631 \cdot \sqrt[3]{H^{2} \cdot c}}{t^{2 / 3}}
$$

...where $q$ is unit rainfall intensity $\left[\mathrm{dm}^{3} \cdot \mathrm{s}^{-1} \cdot \mathrm{ha}^{-1}\right], t \quad$ i $\quad \mathrm{s}$ rainfall duration [min], $H$ is average annual precipitation for a multi-year period [mm], and $c$ is frequency of rainfall of q intensity with exceedance [-].

This model was developed based on a statistical analysis of a set of 79 intense rainfall events recorded in Warsaw in 1837-91 and 1914-25.

\section{Model II}

This is a local rainfall model developed based on data on torrential rainfall events lasting for 5, 10, 15, 30, 60 , and $120 \mathrm{~min}$, recorded by a weather station at the Botanical Garden in the center of Krakow $-5 \mathrm{~km}$ from the studied catchment. Precipitation time series represented 
the maximum annual amounts for accepted times. The geographical coordinates of the rainfall station are N 50³'44”, E 1957'29', height: $206 \mathrm{~m}$ above sea level. Rainfall data come from the period 1906-2010 from the climatology gauge in Krakow. Rainfall data were recorded using the rain gauge. The first stage of the development of measurement data consisted in their verification in terms of uniformity, using the Kruskal-Wallis non-parametric testing method. The results of the test carried out did not give grounds to reject the null hypothesis of homogeneity of the analysed rainfall data for the particular rainfall duration.

Empirical rainfall data for a given duration were approximated using Fisher-Tippett distribution type $\mathrm{I}_{\text {max }}$ and III ${ }_{\min }$. These two distributions were selected because they are commonly used in Poland to describe precipitation distribution and they are recommended by the World Meteorology Organization (WMO). Generalized extreme value distribution has been used for describing the empirical data, but its matching - except for precipitation $t$ $=10$ and $15 \mathrm{~mm}$ - was significantly worse when compared to the obtained Fisher-Tippett distribution type $\mathrm{I}_{\max }$ and III $_{\text {min }}$. Fisher-Tippett distribution type $\mathrm{I}_{\max }$ density function is given by [41]:

$$
f(x, \alpha, \mu)=\alpha e^{-\alpha(x-\mu)-e^{-\alpha(x-\mu)}}, \alpha>0
$$

Distribution parameters $\alpha$ and $\mu$ were determined by maximum likelihood method, where the log-likelihood distribution is represented by the following equation:

$$
\ln L=N \ln \alpha-\alpha \sum_{i=1}^{N} x_{i}+N \alpha \mu-e^{\alpha \mu} \sum_{i=1}^{N} e^{-\alpha \mu}
$$

Quantile of the random variable $x_{p}$ of Fisher-Tippett distribution type $I_{\max }$ was calculated using the formula:

$$
x_{p}=\mu-\frac{1}{\alpha} \ln \ln \frac{1}{1-p}
$$

On the other hand, Fisher-Tippett distribution type III $_{\text {min }}$ density function is defined using the formula:

$$
\begin{gathered}
f(x, \epsilon, \alpha, \beta)=\beta \alpha^{\beta}(x-\epsilon)^{\beta-1} e^{-\alpha^{\beta}(x-\epsilon)^{\beta}}, \\
x>\epsilon, \alpha, \beta>0
\end{gathered}
$$

Function logarithm of the distribution likelihood is as follows:

$$
\begin{gathered}
\ln L=N \ln \beta+N \beta \ln \alpha+(\beta-1) \sum_{i=1}^{N} \ln x_{i}- \\
-\alpha^{\beta} \sum_{i=1}^{N} x_{i}^{\beta}
\end{gathered}
$$

Distribution parameters $\alpha$ and $\beta$ were determined using the maximum likelihood method for a specified lower limit $\varepsilon$. Quantile of the random variable $x_{p}$ of Fisher-
Table 1. Values of $\lambda$ Kołmogorow test for precipitation of different durations.

\begin{tabular}{|c|c|c|}
\hline $\begin{array}{c}\text { Duration } \\
{[\mathrm{min}]}\end{array}$ & $\begin{array}{c}\text { Fisher-Tippett } \\
\text { distribution type } \mathrm{III}_{\min }\end{array}$ & $\begin{array}{c}\text { Fisher-Tippett } \\
\text { distribution type } \mathrm{I}_{\max }\end{array}$ \\
\hline 5 & 0.684 & 0.905 \\
\hline 10 & 0.684 & 0.906 \\
\hline 15 & 0.798 & 0.339 \\
\hline 30 & 0.808 & 0.462 \\
\hline 60 & 0.640 & 0.640 \\
\hline 120 & 0.798 & 0.800 \\
\hline
\end{tabular}

Tippett distribution type III $_{\text {min }}$ was calculated using the formula:

$$
x_{p}=\epsilon+\frac{1}{\alpha}[-\ln (1-p)]^{1 / \beta}
$$

The Kolmogorov test has been used for each theoretical distribution in order to verify the hypothesis about its compliance with the empirical distribution. Test results are presented in Table 1.

Compatibility of the Fisher-Tippett distribution $I_{\max }$ with empirical distribution was tested using the Kolmogorov test. Detailed description of the statistical analysis is provided in the work of Tompór, Walega, and Cupak [42]. Eventually, the output function to develop model II was selected from the examined distributions based on Schwartz information criterion (BIC):

$$
B I C=-\frac{2 \ln L}{N}+\frac{k \ln N}{N}
$$

...where $\operatorname{lnL}$ is the function logarithm of a particular distribution likelihood, $N$ is the number of observations $[-]$, and $k$ is the number of estimated parameters [-].

The model for which information criterion (BIC) received the lowest value was chosen as the best. Calculation results are presented in Table 2.

The analysis showed that for all rainfall durations (except for $t=5 \mathrm{~min}$ ), lower values AIC and BIC were achieved for Fisher-Tippett distribution type $\mathrm{I}_{\max }$, and this distribution has become the basis for the development of model II.

The result was a local formula determining the amount of precipitation for a given duration and probability of exceedance in the following form:

$$
\begin{gathered}
P_{\max (t, p)}=[4,119 \ln (t)-0,267]- \\
-\frac{1}{\left[0,835 \cdot t^{-0,406}\right]} \ln \ln \frac{1}{1-p}
\end{gathered}
$$

...where $t$ is rainfall duration [min] and $p$ is probability of exceedance $[-]$. 
Table 2. Values of AIC and BIC criterion for analyzed distributions of precipitation of different durations (modified after: [38]).

\begin{tabular}{|c|c|c|}
\hline $\begin{array}{c}\text { Duration } \\
{[\mathrm{min}]}\end{array}$ & $\begin{array}{c}\text { Fisher-Tippett } \\
\text { distribution type } \text { II }_{\min }\end{array}$ & $\begin{array}{c}\text { Fisher-Tippett } \\
\text { distribution type } \mathrm{I}_{\max }\end{array}$ \\
\hline 5 & $\mathbf{4 . 8 2 3}^{*}$ & 4.853 \\
\hline 10 & 5.761 & $\mathbf{5 . 7 5 6}$ \\
\hline 15 & 6.262 & $\mathbf{6 . 0 9 0}$ \\
\hline 30 & 6.785 & $\mathbf{6 . 6 1 5}$ \\
\hline 60 & 7.378 & $\mathbf{7 . 0 9 4}$ \\
\hline 120 & 7.537 & $\mathbf{7 . 2 1 6}$ \\
\hline
\end{tabular}

* bold BIC criterion values refer to distribution recommended for further use

The equation is valid for rainfall durations from $t=5 \mathrm{~min}$ to $t=120 \mathrm{~min}$, and for the probability of $p=1 \%$ to $p=100 \%$. Model II does not take into account the spatial variability of rainfall because it was developed based on data obtained from a weather station. Due to the location of the Botanical Garden rainfall station in the centre of Krakow, it can be assumed that the developed model is representative for the part of the city characterized by its compact architecture. Because of the lack of reliable precipitation data from rainfall stations located in the vicinity of the city, it has been assumed for the present moment that the developed model is also valid for areas of the city situated outside its centre.

The size of the rainwater drainage system at stage II was based on Polish standard PN-EN 752: 2008. The frequency of design rainfall c was assumed to be two years. The volume of rainwater $Q$ flowing from the catchment area was established based on the formula [40]:

$$
\boldsymbol{Q}=\psi \cdot \boldsymbol{q} \cdot \boldsymbol{F}
$$

...where $\psi$ is surface runoff coefficient $[-], q$ is design rainfall intensity $\left[\mathrm{dm}^{3} \cdot \mathrm{s}^{-1} \cdot \mathrm{ha}^{-1}\right]$, and $F$ is drainage area [ha].

Based on data concerning designed land development, weighted average flow coefficient was calculated depending on the partial surface type and amounts to $\psi=0.8$. For calculating design rainfall intensity q (Formula 1), the amount of the average annual precipitation for Krakow was assumed to be $680 \mathrm{~mm}$. Time $\mathrm{t}$ in formula $q$ (Formula 1) is the sum of three times: time of area concentration, flow time of rainwater through the channel, and time of filling up the rainwater collecting pipes. The assumed duration of the design rainfall was 10 minutes. The total drainage area F was 0.9 ha. For the purpose of the calculations, the catchment area was divided into three subcatchments $(F 1=0.32$ ha, F2 $=0.2$ ha, and F3 $=0.38$ ha $)$. The designed collecting pipe was also divided into three sections: $\mathrm{L} 1=30.9 \mathrm{~m}, \mathrm{~L} 2=48.4 \mathrm{~m}$, and L3 $=57.1 \mathrm{~m}$. The rainwater pipes were made from U-PVC of SDR 34 Lite SN8 type produced by the Wavin Company. For se- lecting diameters and hydraulic calculations of the collecting pipe we used the Wavin Pipe Choice (v. 1.4) computer program. As recommended, the collecting pipe filled 70\% of its diameter. The results of hydraulic calculations and parameters of individual collecting pipes are presented in Tables 3 and 4.

Verification of the collecting pipe hydraulic capacity at stage III was made using numerical modeling in the Storm Water Management Model SWMM [43-45] program, which was created by the Water Supply and Water Resources Division of the U.S. Environmental Protection Agency's National Risk Management Research Laboratory as a result of work and research carried out in order to assess and reduce risks for human health and environment. SWMM now provides an integrated graphical environment for editing catchment input data and flow routing at single-event and long-term scales, together with first-order water quality simulation. The surface runoff module in SWMM is applied to a set of subcatchments within which precipitations occur, and water and contaminant outflow emerges. The sewer system module reflects transport via the system of pipelines, conduits, containers, pumps, and regulators. It is possible to use the application to analyze in detail sanitary sewer, storm water runoff and the combined one for both branched as well as ring systems, in each stage of construction [46-47]. Structure of the catchment reflected in the model takes into account the requirement that the partial catchment area does not exceed a few hectares [33, 48-50].

The analysis was performed for design rainfall loading of the frequency $c=2$ and $c=3$, required to check the frequency of maximum water damming level (the level

Table 3. Summary of the catchment area and runoff discharge parameters.

\begin{tabular}{|c|c|c|c|c|c|}
\hline Section & $\begin{array}{c}\text { Length } \\
L_{n} \\
{[\mathrm{~m}]}\end{array}$ & $\begin{array}{c}\text { Area } \\
F_{n} \\
{[\mathrm{ha}]}\end{array}$ & $\begin{array}{c}\text { Rainfall } \\
\text { intensity } \\
q_{n} \\
{\left[\mathrm{dm}^{3} \cdot \mathrm{s}^{-1}\right.} \\
\left.\cdot \mathrm{ha}^{-1}\right]\end{array}$ & $\begin{array}{c}\text { Runoff } \\
\text { ratio } \\
\psi_{n} \\
{[-]}\end{array}$ & $\begin{array}{c}\text { Rainwater } \\
\text { discharge } \\
Q_{n} \\
{\left[\mathrm{dm}^{3} \cdot \mathrm{s}^{-1}\right]}\end{array}$ \\
\hline S04-S03 & 30.9 & 0.32 & 139.08 & 0.8 & 35.60 \\
\hline S03-S02 & 48.4 & 0.20 & 139.08 & 0.8 & 57.86 \\
\hline S02-S0i & 57.1 & 0.38 & 139.08 & 0.8 & 100.14 \\
\hline
\end{tabular}

Table 4. Parameters of the individual sections of the collecting pipes.

\begin{tabular}{|c|c|c|c|c|c|}
\hline Section & $\begin{array}{c}\text { Length } \\
L_{n} \\
{[\mathrm{~m}]}\end{array}$ & $\begin{array}{c}\text { Bottom } \\
\text { slope } \\
i_{n} \\
{[\% 0]}\end{array}$ & $\begin{array}{c}\text { Diameter } \\
d_{n} \\
{[\mathrm{~mm}]}\end{array}$ & $\begin{array}{c}\text { Fill } \\
h_{n} \\
{[\%]}\end{array}$ & $\begin{array}{c}\text { Velocity } \\
v_{n} \\
{\left[\mathrm{~m} \cdot \mathrm{s}^{-1}\right]}\end{array}$ \\
\hline S04-S03 & 30.9 & 15.6 & 250 & 51.2 & 1.59 \\
\hline S03-S02 & 48.4 & 15.6 & 250 & 68.2 & 1.83 \\
\hline S02-S0i & 57.1 & 15.6 & 315 & 68.6 & 2.08 \\
\hline
\end{tabular}


of the water table in the catchment pit at the level of the ground elevation surface). The rainfall duration was assumed to be twice as long as the calculated concentration time, as recommended by Kotowski [31]. As the SWMM model requires entering the precipitation hyetograph, we used the Euler method and assumed rainfall distribution of type II [51]. The calculations were performed for the precipitation with time step $\Delta t=5 \mathrm{~min}$.

The SWMM program was used to develop an image of the designed rainwater collecting pipe and elementary catchments: F1, F2, and F3. Precipitation loss due to evapotranspiration, interception, surface retention, and infiltration was determined by the Soil Conservation Service (SCS) method, assuming an appropriate curve number $(\mathrm{CN})$ value (depending on land cover and soil conditions) [52]. CN value for normal catchment moisture level was used. Water depth on the sub-catchment surface was calculated using the equation of water balance. Surface runoff in SWMM was calculated from Manning's equation [46]:

$$
Q_{s}=W \cdot \frac{1.49}{n}\left(d-d_{p}\right)^{5 / 2} \cdot i_{c}^{1 / 2}
$$

...where $Q_{s}$ is surface runoff $\left[\mathrm{m}^{3} \cdot \mathrm{s}^{-1}\right], W$ is catchment width [m], $n$ is Manning's roughness of catchment $[-], d_{p}$ is maximum depression storage $[\mathrm{m}], d$ is depth of water over the sub-catchment [m], and $i_{c}$ is sub-catchment slope $\left[\mathrm{m} \cdot \mathrm{m}^{-1}\right]$.

$D_{p}$ values have been adopted as for sealed lands according to ASCE 1992 [53]. Manning roughness coefficient was assumed depending on the land cover in the individual sub-catchments and based on the tables in [43]. Catchment width W was assumed for the catchments symmetrical to the rainwater collecting pipe to be twice the length of the channel. Transformation of the discharge inside the collecting pipe was performed for unsteady flow using a dynamic wave. Dynamic wave routing solves the complete one-dimensional Saint Venant flow equations and therefore produces the most theoretically accurate results. These equations consist of the continuity and momentum equations for conduits and a volume continuity equation at nodes [54]:

$$
\begin{gathered}
\frac{\delta Q}{\delta t}+\frac{\delta}{\delta x}\left(\frac{\beta Q^{2}}{A}\right)+g A \frac{h}{\delta x}+g \frac{n^{2}}{R_{h}^{4 / 3}} \frac{|Q| Q}{A}=0 \\
\frac{\delta A}{\delta t}+\frac{\delta Q}{\delta x}=0
\end{gathered}
$$

... where $R_{h}$ is hydraulic radius [m], $A$ is stream cross sectional area $\left[\mathrm{m}^{2}\right], Q$ is flow rate $\left[\mathrm{m}^{3} \cdot \mathrm{s}^{-1}\right], \beta$ is dimensionless velocity coefficient $[-], n$ is roughness coefficient $\left[\mathrm{s} \cdot \mathrm{m}^{-1 / 3}\right]$, $g$ is gravity $\left[\mathrm{m} \cdot \mathrm{s}^{-1}\right]$, and $h$ is channel depth $[\mathrm{m}]$.

We decided on hydraulic modelling of water flow in the collecting pipe by means of a system of equations for dynamic wave. The reason for adopting such a solution was the lack of side channels whose tributaries would cause disturbance in the flow of water in the main collecting pipe. And therefore it was assumed that gradually varied steady flow is in the collecting pipe as the slope of the channel bottom is small; the Froude number calculated for individual sections of the collecting pipe was less than 1 (fluctuation from 0.55 to 0.97 ).

The system of equations was solved numerically by the finite differences methods. Free discharge from the modeled section of the channel and thus lack of backflow were assumed.

Verification of the hydraulic capacity of the collecting pipe dimensioned at stage II was carried out for rainfall with duration equal to the time of catchment runoff and for the time being twice the runoff time, as recommended by Kotowski [31]. Additionally, for the collecting pipe designed as per two rainfall models, we simulated the system operation for extremely high rainfall intensity of $132.0 \mathrm{dm}^{3} \cdot \mathrm{s}^{-1} \cdot \mathrm{ha}^{-1}$, assumed for Krakow as recommended by the Water and Sewage Company.

\section{Results and Discussion}

As mentioned in the introduction, accurate determination of the design rainfall at the stage of designing the drainage system is very important. This study used two rainfall models.

Fig. 2 shows the curves of rainfall intensity, calculated using these models at a frequency of $\mathrm{c}=2$ and $\mathrm{c}=3$.

The calculation outcomes indicated that the rainfall intensity for $\mathrm{c}=2$, as defined from model II, was higher than in model I for the time interval from 5 to $65 \mathrm{~min}$, and for the frequency $\mathrm{c}=3$ for the entire time range. The greatest differences, which are particularly important for the design practice, were observed for t $30 \mathrm{~min}$ (precipitation intensity in model II was on average $24 \%$ higher than in model I). A difference between the intensities determined by means of these two models disappeared with increasing rainfall duration, but increased with decreasing rainfall frequency c. Fig. 3 compares the results of the rainfall

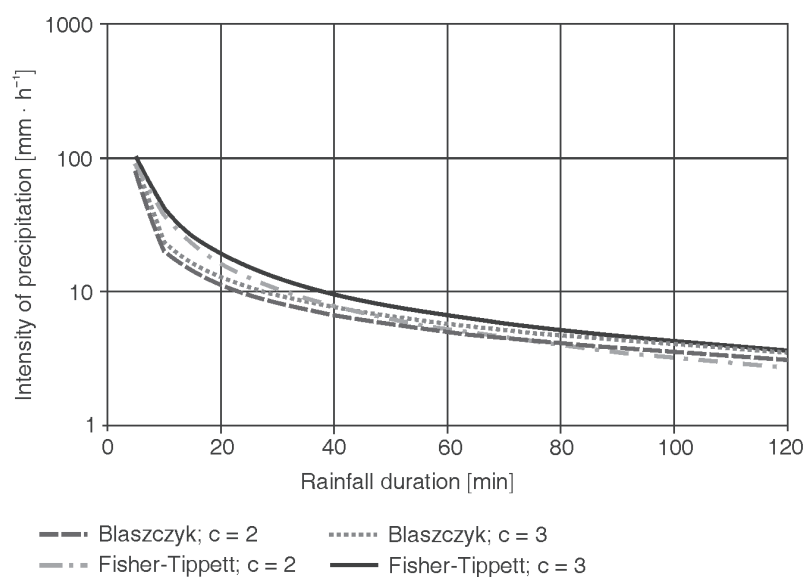

Fig. 2. Intensity of precipitation calculated using individual models at a frequency of $\mathrm{c}=2$ and $\mathrm{c}=3$. 
intensity for $\mathrm{t}=15 \mathrm{~min}$ and different probabilities obtained from both models against the observed precipitation. The course of the curves indicates that the local model II more accurately described the empirical rainfall sequence in the range of probability from $\mathrm{p}=5$ to $\mathrm{p}=100 \%$, as compared to the commonly used model I. It can be concluded that this model is much more suitable for the estimation of torrential rainfall intensity in the range of probabilities required in Poland and Europe for the dimensioning of the rainwater drainage system and its verification in terms of hydraulic capacity. According to the research conducted for Wrocław by Kotowski [55-56] as well as Kotowski and Kazimierczak [57], in order to estimate the quantile of the amount of precipitation the best option to apply is probabilistic models based on Fisher-Tippet III $_{\text {min }}$ distribution and generalized triple exponential distribution. In turn, Licznar, Łomotowski, and Rojek [58] found that the physical model based on the general hyperbole equation correctly describes the actual volume of the precipitation for Wroclaw.

The graph in Fig. 3 shows that rainfall intensity $q$ equals $135.0 \mathrm{dm}^{3} \cdot \mathrm{s}^{1} \cdot \mathrm{ha}^{-1}$, calculated from model II for $\mathrm{t}=15 \mathrm{~min}$ and probability $p=50 \%$, can be achieved in model I for a probability of $p=20 \%$. As a consequence, using rainfall model II leads to assuming greater discharge flows and constructing collecting pipes of greater diameters. The lower rainfall intensity obtained from model I results from assuming an incorrect number of rainfall events at

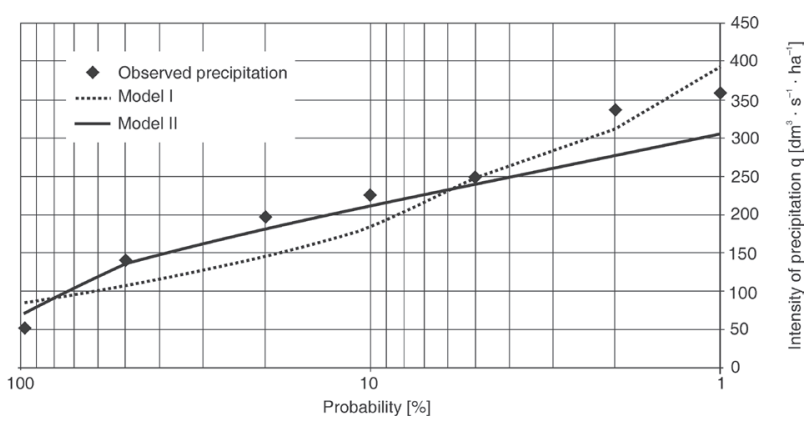

Fig. 3. Rainfall intensity computed using models I and II for $\mathrm{t}=15 \mathrm{~min}$ and various probabilities of occurrence.

Table 5. Proportional values of errors of calculated precipitation intensity according to different models in comparison to observed precipitation.

\begin{tabular}{|c|c|c|}
\hline Probability [\%] & Model I & Model II \\
\hline 1 & -8.4 & 15.3 \\
\hline 2 & 7.3 & 17.8 \\
\hline 5 & 0.5 & 3.7 \\
\hline 10 & 18.7 & 6.0 \\
\hline 20 & 26.3 & 8.0 \\
\hline 50 & 23.7 & 3.1 \\
\hline 100 & -67.6 & -38.6 \\
\hline
\end{tabular}

the stage of Formula (1), and incorrect assumptions during empirical data approximation with the adopted regression equations [41]. Table 5 contains the errors in rainfall intensity calculated for the individual precipitation events (at $\mathrm{t}=15 \mathrm{~min}$ ) and compared to the observed values.

Careful analysis of Table 5 shows that above probability of $\mathrm{p}=5 \%$, the errors concerning rainfall intensity calculated from model II were smaller when compared to the observed rainfall, than those obtained from model I.

Differences in rainfall intensity obtained from models I and II affected the results of numerical calculations in the SWMM program. Table 6 presents the parameters of the sub-catchments, and Tables 7 and 8 show the results of the water balance obtained in the SWMM program for individual sub-catchments, for rainfall intensity calculated by models I and II, frequency $\mathrm{c}=2$ and duration $\mathrm{t}=15$ and $\mathrm{t}=30 \mathrm{~min}$.

Peak flow rate values for model II were on average $10 \%$ higher than for model I. Assuming higher rainfall intensity leads to increasing the runoff flow volume, which is very important in terms of channel detention.

The most important test, confirming the usefulness of the local rainfall model for sizing the rainwater drainage system, is the assessment of the collecting pipe filling during rainfall of frequency recommended for checkout calculations - in this case $\mathrm{c}=3$. The calculation outcomes are presented in Figs 4 and 5.

It can be concluded that assuming free runoff, when the modeled sewer system is sized for the rainfall calculated using model I, the system will be operating under pressure on the whole length of the collecting pipe (except for the section where the collecting pipe is filled up to $95 \%$ of its capacity). In all sewage sumps (except the first) rainwater damming level will be exceeded. Maximum flow velocity in the collecting pipe will be from 1.95 to $1.30 \mathrm{~m} \cdot \mathrm{s}^{-1}$.

When sizing of the drainage system is based on rainfall intensity calculated from model II, the collecting pipe will operate under pressure only in its final section. Maximum filling of the collecting pipe will be from $70 \%$ to $100 \%$. Only in the last sewage sump will an insignificant elevation of the rainwater be observed. Maximum flow

Table 6. Catchment parameters entered into the SWMM model.

\begin{tabular}{|c|c|c|c|}
\hline Parameter & $\begin{array}{c}\text { F1 } \\
\text { Catchment }\end{array}$ & $\begin{array}{c}\text { F2 } \\
\text { Catchment }\end{array}$ & $\begin{array}{c}\text { F3 } \\
\text { Catchment }\end{array}$ \\
\hline $\begin{array}{c}\text { Catchment area } \\
\text { [ha] }\end{array}$ & 0.32 & 0.2 & 0.38 \\
\hline $\begin{array}{c}\text { Catchment width } \\
{[\mathrm{m}]}\end{array}$ & 62.0 & 98.0 & 82.0 \\
\hline $\begin{array}{c}\text { Calculated } \\
\text { catchment slope } \\
\mathrm{i}_{\mathrm{c}}[\%]\end{array}$ & 2.0 & 1.6 & 2.7 \\
\hline $\begin{array}{c}\text { Catchment } \\
\text { imperviousness } \\
\text { U [\%] }\end{array}$ & 70.0 & 70.0 & 72.0 \\
\hline CN parameter [-] & 85.0 & 85.6 & 85.0 \\
\hline
\end{tabular}




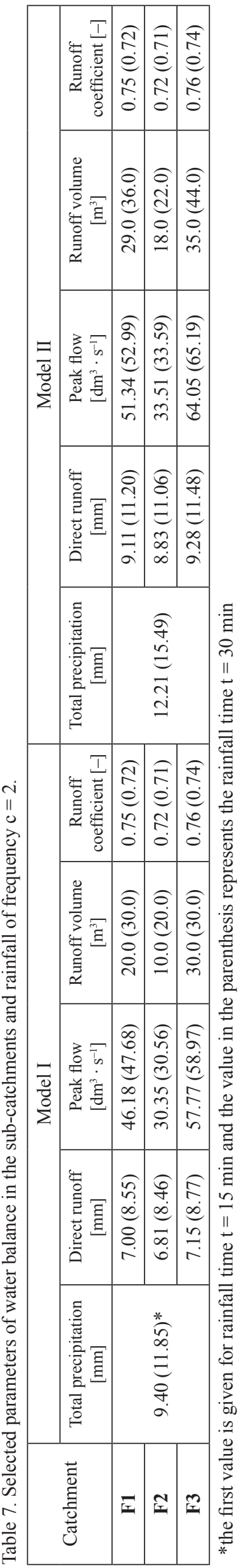

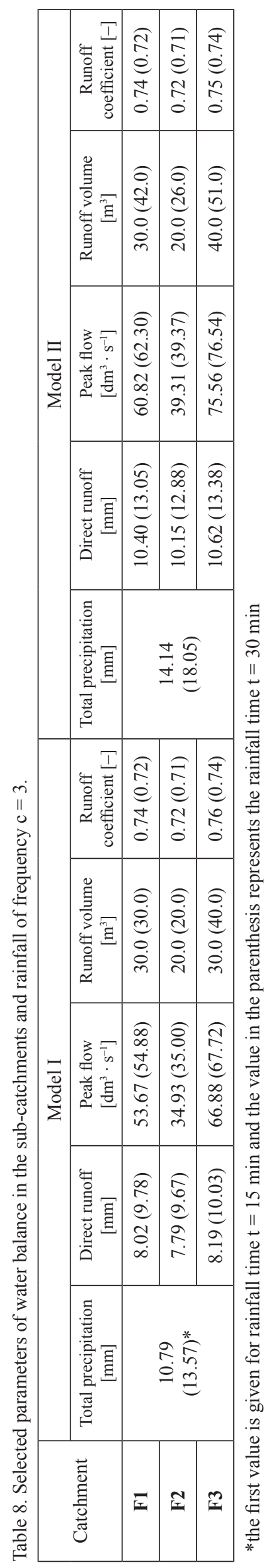

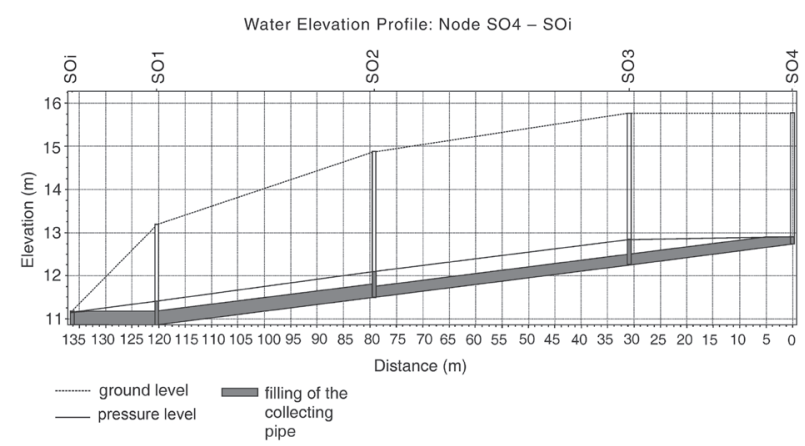

Fig. 4. Profile of the collecting pipe loaded with runoff generated by rainfall lasting for $\mathrm{t}=30 \mathrm{~min}$ and of frequency $\mathrm{c}=3$, calculated from model I.

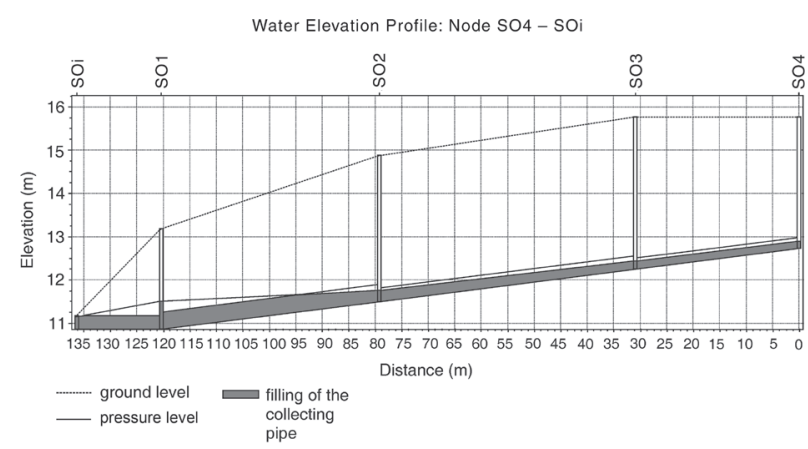

Fig. 5. Profile of the collecting pipe loaded with runoff generated by rainfall lasting for $\mathrm{t}=30 \mathrm{~min}$ and of frequency $\mathrm{c}=3$, calculated from model II.

velocity in the collecting pipe will range from 1.73 to $1.50 \mathrm{~m} \cdot \mathrm{s}^{-1}$. The performed calculations showed that a collecting pipe designed based on the local rainfall model had greater storage capacity, thus allowing for an interception of greater runoff flows without the risk of sewer sumps overflowing. Live volume of the channel calculated from model I is $29.7 \mathrm{~m}^{3}$, and from model II it is $36.0 \mathrm{~m}^{3}$, i.e., nearly $18 \%$ higher. A channel design based on rainfall model II will be much more reliable than one designed for the precipitation volume obtained from model I. Similar observations can be found in the research made by Kotowski [56]. It is also very important in the context of climatic changes, manifested, e.g., by increased frequency of torrential rains that cause local flash floods [59-62]. Greater storage capacity of the channel, determined using model II, serves as an additional buffer to intercept excessive amounts of rainwater.

Additional simulation, in the conditions of extremely intense precipitation, was conducted for the dimensions of the collecting pipes determined based on the runoff flows calculated in models I and II. The extreme precipitation was rainfall of intensity $132.0 \mathrm{dm}^{3} \cdot \mathrm{s}^{-1} \cdot \mathrm{ha}^{-1}$ recorded at the rainfall station in Krakow. This was maximum value of precipitation, equaling $99 \mathrm{~mm}$, and it occurred during a precipitation event on 9 September 1963. A hail-producing thunderstorm occurred that day. This was also the greatest amount precipitation in the history of observations at the 
precipitation station, representing approximately 14\% of long-term average annual precipitation [63-64]. The occurrence of abnormally high precipitation, including the aforementioned episode of 1963, is related to the synoptic situation. As described by Twardosz and Niedźwiedź [65], high averages of daily precipitation occur in the advective movement of air masses from the north, northeast, and northwest. Figs 6 and 7 depicts water elevation profiles of the collecting pipes, sized on the basis of rainfall calculated from models I and II, in the conditions of the rainfall of 9 September 1963, with $\mathrm{t}=15 \mathrm{~min}$ and depth $\mathrm{H}=55 \mathrm{~mm}$.

The simulations showed that in the case of such a rainfall event, the maximum runoff from sub-catchments would amount to $721.3 \mathrm{dm}^{3} \cdot \mathrm{s}^{-1}$, summing up to a total runoff volume of $436 \mathrm{~m}^{3}$. The calculations clearly indicate that if the collecting pipe is dimensioned based on the precipitation obtained from model I, system overloading and sewage sump overflows will be observed for almost the entire length of the drainage system (Fig. 6). Only the last sump will not overflow. The amount of rainwater overflowing from drainage will be $138 \mathrm{~m}^{3}$, thus amounting to nearly $32 \%$ of the total catchment runoff. The channel hydraulic overload will be smaller if its dimension is determined using rainfall calculated in the local model II, employing the Fisher-Tippet distribution of $\mathrm{I}_{\max }$ type. In this situation, rainwater overflow will be observed only in the first sump and its amount will be $46 \mathrm{~m}^{3}$, i.e., only $11 \%$ of the total runoff volume. These results clearly indicate that

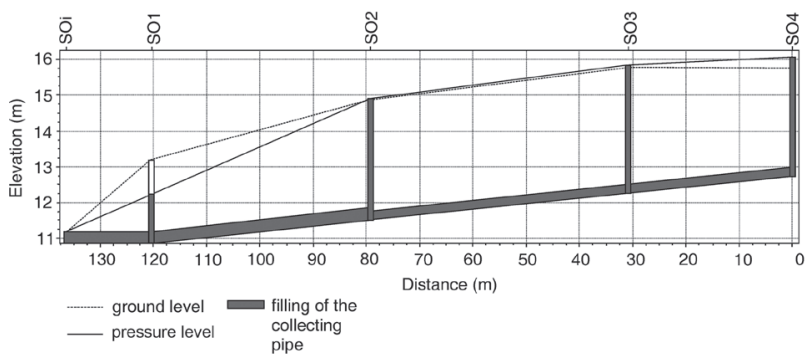

Fig. 6. Filling of the collecting pipe whose size is based on the rainfall calculated in model I, simulated for the rainfall event of 9 September 1963.

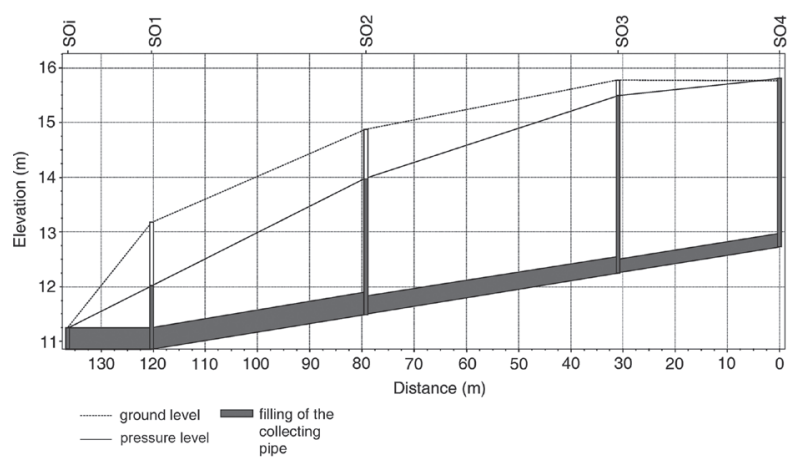

Fig. 7. Filling of the collecting pipe whose size is based on the rainfall calculated in model II, simulated for the rainfall event of 9 September 1963. the use of the local precipitation model allows for designing safer drainage systems that ensure the interception of almost the entire runoff generated by rainfall significantly exceeding design values. Due to the very small catchment area, once the rainwater drainage system is ready, it is necessary to carry out tests, including calibration of parameters of the applied model based on recorded precipitation and measured runoff from the drainage system. This will allow in the future an exact description of the catchment response to precipitation episodes featuring varied character.

\section{Conclusions}

The rainwater collecting pipe operation in the conditions of rainfall events calculated using two different models has been analyzed in the following paper from the hydraulic aspect. Model I is recommended for use across Poland, while model II, having a local character, has been developed based on Fisher-Tippet distribution type $\mathrm{I}_{\text {max }}$. The dimensions of the collecting pipe were specified in two variants (depending on the employed precipitation model). Finally, the hydraulic capacity of the channel was verified under different conditions of rainwater volume. The following conclusions have been made based on the presented research:

1. The calculations outcomes indicate that the design rainfall intensity specified using model II was higher for the time interval recommended for drainage system design than in model I. The difference between intensities defined from both models decreases as rainfall increases, while it increases as rainfall frequency decreases.

2. Larger values of precipitation intensity causing the flow of sewage in culmination for model II are higher on average by $10 \%$ in comparison to model II.

3. The numerical calculations carried out using SWMM showed that the collecting pipe design based on the rainfall intensity from model II was capable of intercepting the designed runoff volume, offering a storage volume over a substantial length of the pipe. Using data obtained by means of the model I the drainage system, works under pressure along its entire length and accumulation of wastewater occurs in virtually all catch pits. In both cases, there was no discharge of wastewater from catch pits to the ground surface. Due to the existing storage volume in the channel design based on rainfall model II, it will perform with greater reliability - even during extreme rainfall featuring very low frequency of occurrence.

\section{Acknowledgements}

This publication was funded by statutory activity of the Department of Sanitary Engineering and Water Management (No. DS-3347/KISiGW/15, entitled 'Improving the scientific basis for development of water and waste- 
water management, design, construction, and exploitation of rural water supply and sewage systems and the role of small retention in the formation of surface waters').

\section{References}

1. SHUSTER W.D., BONTA J., THURSTON H., WARNEMUENDE E., SMITH D.R. Impacts of impervious surface on watershed hydrology: A review. Urban Water J. 2 (4), 263, 2005.

2. O'DRISCOLL M., CLINTON S., JEFFERSONA., MANDA A., MCMILLAN S. Urbanization effects on watershed hydrology and in-stream processes in the Southern United States. Water. 2, 605, 2010.

3. LIZÁRRAGA-MENDIOLA L., VÁZQUES-RODRÍRUEZ G., BLANCO-PIÑÓN A., RANGEL-MARTÍNEZ Y., GONZÁLEZ-SANDOVAL M. Estimating the rainwater potential per household in an urban area: Case study in Central Mexico. Water. 7, 4622, 2015.

4. KACZOR G., BUGAJSKI P. Impact of snowmelt inflow on temperature of sewage discharged to treatment plant. Pol. J. Environ. Stud. 12 (2), 381, 2012.

5. MIGUEZ M.Z., DE MAGALHAES L.P.C., Urban flood control, simulation and management - an integrated approach. In: de Pina Filho A.C., de Pina A.C., eds. Methods and Techniques in Urban Engineering. Intech, Rijeka. 2010.

6. TUCCI C.E.M. Urban Flood Management, WMO, Cap-Net, Cordoba. 2008

7. MROWIEC M. The development of sewer systems in the context of preventing phenomena of urban flooding. In: Łomotowski, J. ed. Storm Water and Extreme Events. Seidel-Przywecki, Warszawa. 2011 [In Polish].

8. PRZYBYŁA CZ., BYKOWSKI J., MROZIK K., NAPIERAŁA M. The role of rater and drainage system infrastructure in the process of suburbanization. Annual Set the Environment Protection. 13, 769, 2011.

9. MROZIK K., PRZYBYŁA CZ., PYSZNY K. Problems of the integrated urban water management. The case of the Poznań Metropolitan Area (Poland). Annual Set the Environment Protection. 17, 230, 2015.

10. CHMIELEWSKA A., WIDOMSKI M.K., MUSZ A., LAGOD G., MAZUREK W. Numerical modeling in quantitative and qualitative analysis of storm sewage system operational conditions. Proceedings Ecopole. 6 (2), 487, 2012.

11. BUTLER D., DAVIES J.W. Urban Drainage, $3^{\text {rd }}$ ed. Spon Press, London. 2011.

12. WANNIARACHCHI S.S., WIJESEKERA N.T.S., Using SWMM as a tool for floodplain management in ungauged urban watershed. Engineer. Journal of the Institution of Engineers. 45 (1), 1, 2012

13. HOU P., REN Y., ZHANG Q., LU F., OUYANG Z., WANG $\mathrm{X}$., Nitrogen, and phosphorus in atmospheric deposition and roof runoff. Pol. J. Environ. Stud. 21 (6), 1621, 2012.

14. WRIGHT D.B., SMITH J.A., VILLARINI G., BAECK M.L. The hydroclimatology of flash flooding in Atlanta. Water Resour. Res. 48, W04524, 2012

15. NORBIATO D., BORGA M., SANGATI M., ZANON F. Regional frequency analysis of extreme precipitation in the eastern Italian Alps and the August 29, 2003 flash flood. J. Hydrol. 345, 149, 2007.

16. MEIERDIERCKS K.L., SMITH J.A., BAECK M.L., MILLER A.J. Analyses of urban drainage network structure and its impact on hydrologic response. JAWRA. J. Am.
Water Resour. As. 46, 932, 2010.

17. MCMILLAN H., JACKSON B., CLARK M., KAVETSKI D., WOODS R. Rainfall uncertainty in hydrological modeling: An evaluation of multiplicative error models. J. Hydrol. 400, 83, 2011.

18. LICZNAR P., ŁOMOTOWSKI J. Analysis of time frequency distribution of Maxima intensities of storms in the City of Wroclaw. Ochrona Środowiska. 27 (2), 25, 2005. [In Polish]

19. MANNINA G., FRENI G.,VIVIANI G., SAEGROV S., HAFSKJOLD L.S. Integrated urban water modeling with uncertainty analysis. Water Sci. Technol. 54 (6-7), 379, 2006.

20. KAVETSKI D., KUCZERA G., FRANKS S.W. Bayesian analysis of input uncertainty in hydrological modeling: 1. Theory. Water Resour. Res. 42 (3), 2006.

21. BÁRDOSSY A., DAS T. Influence of rainfall observation network on model calibration and application. Hydrol. Earth Syst. Sc. 12, 77, 2008

22. MOULIN L., GAUME E., OBLED C. Uncertainties on mean areal precipitation: Assessment and impact on streamflow simulations. Hydrol. Earth Syst. Sc. 13, 99, 2009.

23. KACZMAREK Z. Statistical Methods in Meteorology and Hydrology. Press of Communication and Telecommunication, Warsaw. 1970 [In Polish].

24. KOTOWSKI A., KAŹMIERCZAK B., DANCEWICZ A., Precipitation modeling for sewage measuring. Studies in Engineering. 68, 2010.

25. WEQGLARCZYK S. On the correctness of the Błaszczyk equations for design rainfall calculations. Infrastructure and Ecology of Rural Areas. 3 (IV), 63, 2013 [In Polish].

26. BONI G., PARODI A., RUDARI R. Extreme rainfall events: Learning from raingauge time series. J. Hydrol. 327, 304, 2006.

27. FITZGERALD D.L. Analysis of extreme rainfall using the log-logistic distribution. Stoch. Env. Res. Risk A. 19, 249, 2005.

28. KYSLEY J., PICEK J. Probability estimates of heavy precipitation events in a flood-prone central-European region with enhanced influence of Mediterranean cyclones. Advances in Geosciences. 12, 43, 2007.

29. VILLARINI G., SMITH J.A., BAECK M.L., VITOLO R., STEPHENSON D.B., KRAJEWSKI W.F. On the frequency of heavy rainfall for the Midwest of the United States. J. Hydrol. 400, 103, 2011.

30. WRIGHT D.B., SMITH J.A.,VILLARINI G., BAECK M.L. Estimating the frequency of extreme rainfall using weather radar and stochastic storm transposition. J. Hydrol. 488, 150, 2013.

31. KOTOWSKI A. Basics for Safer Dimensioning Drainage Areas. Seidel-Przywiecki Press, Warsaw. 2011 [In Polish].

32. PUBLIC WORKS AGENCY STANDARDS. Storm Drainage Design Guidelines. Engineering Design \& Row Management Division 2006. City of Oakland, Ca. 2006.

33. SKOTNICKI M., SOWIŃSKI M.A. Comparative Study of Approaches for Hydraulic Width Determination of SubCatchments in Urban Stormwater Model. In: International Symposium on Water Management and Hydraulic Engineering, Ohrid, Macedonia 1-5.09.2009, 419, 2009.

34. SKOTNICKI M., SOWIŃSKI M. The influence of depression storage on runoff from impervious surface of urban catchment. Urban Water J. 12 (3), 207, 2015.

35. CITY HALL OF KRAKOW. Report after the Flood: May and June 2010. Cracow. 2010 [In Polish].

36. ADAMOWSKI K. Regional analysis of annual maximum and partial duration flood data by nonparametric and L-moment methods. J. Hydrol. 229, 219, 2000.

37. YANGT., QUANXIS.,ZHEN-CHUNH., XICH.,ZENGXIN 
Z., CHONG-YU X., LIMIN S. Regional frequency analysis and spatio-temporal pattern characterization of rainfall extremes in the Pearl River Basin, China. J. Hydrol. 380, 386, 2010.

38. DOTTO C.B.S.,KLEIDORFER M., DELETIC A., RAUCH W., MCCARTHY D.T., Impacts of measured data uncertainty on urban stormwater models. J. Hydrol. 508, 28, 2014.

39. ZAWILSKI M., BRZEZINSKA A. Areal rainfall intensity distribution over an urban area and its effect on a combined sewerage system. Urban Water J. 11 (7), 532, 2014.

40. BŁASZCZYK P., ROMAN M., STAMATELLO H., Sewer System. Arkady Press, Warsaw. 1974 [In Polish].

41. WĘGLARCZYK S. Statistic in Environmental Engineering. Press of University of Technology, Krakow. 2010 [In Polish].

42. TOMPÓR P., WALEGA A., CUPAK A., Modelling of storms in aspect of project of rainwater drainage system in urbanized catchments. In: Hydrology in Engineering and Water Management, Banasik, K., Hejduk, L., Kaznowska, E. eds., T. 1. Monograph of Water Management Committee Polish of Science Academy, Warsaw. 2014 [In Polish].

43. EPA SWMM v.5.018. Manual v.5.0. US Environmental Protection Agency. Available online: http:/www.epa.gov/ ednnrmrl/models/swmm/ (accessed: 6 August 2014).

44. SLYS D., STEC A. Hydrodynamic modeling of the combined sewage system for the city of Przemysl. Environ. Prot. Eng. 38 (4), 99, 2012.

45. BARSZCZ M. Influence of applying infiltration and retention objects to the rainwater runoff on a plot and catchment scale - case study of Służewiecki Stream subcatchment in Warsaw. Pol. J. Environ. Stud. 24 (1), 57, 2015.

46. KOWALSKAB., KOWALSKI D., LAGOD G., WIDOMSKI M.K. Modelling of Hydraulics and Pollutants Transport in Sewer System. With Exemplary Calculations in SWMM. University of Technology in Lublin, Lublin. 2013.

47. ELLIS J.B., VIVATTENE CH. Stormwater modeling and sustainable management in highly urbanized areas. In: Handbook of Hydrology. Environmental Hydrology and Water Management. Eslamian, S. ed. CRC Press, London, 347, 2014

48. ZAWILSKI M., Integration of urban watershed in the storm sewage simulation. Gas, Water and Sanitation systems. 6, 28, 201. [in Polish].

49. ZAWILSKI M., SAKSON G. Use of the SWMM programme in the sewage systems modeling. In: Problems in the rainwater management Łomotowski, J. ed. Wyd. SeidelPrzywecki Sp. z o.o., Warszawa, 155, 2008 [In Polish].

50. ACOSTA I.A. Discretization in urban watersheds. In: Handbook of Hydrology. Modelling, Climate Change and Variability. Eslamian, S. ed. CRC Press London, 191, 2014.

51. SCHMITT T.G. Commentar to ATV-A118 Hydraulics calculated in drainage system. Seidel-Przywecki, Warszawa. 2000.

52. KOWALIK T., WALEGA A. Estimation of $\mathrm{CN}$ parameter for small agricultural watersheds using asymptotic functions. Water. 7 (3), 939, 2015.

53. ASCE Design and Construction of Urban Stormwater Management Systems, ASCE Publications, New York, NY. 1992.

54. EVEN S., MOUCHEL J.-M., SERVAIS P., SEIDL M., POULIN M. Modelling oxygen deficits in the Seine River downstream of combined sewer overflows. Ecol. Model. 173, 177, 2004.

55. KOTOWSKI A. Principles of modeling rainwater for the design of drainage areas. In: Rainwater and extreme events. Łomotowski, J. ed. Wyd. Seidel-Przywecki Sp z o.o., Warszawa, 163, 2011 [In Polish].

56. KOTOWSKI A. Basics for Safer Dimensioning Drainage Areas. T. 1 Sewerages systems. Seidel-Przywiecki Press, Warsaw. 2015 [In Polish].

57. KOTOWSKI A., KAZIMIERCZAK B., Verification of the generalized exponential distribution for rainwater modeling. Gas, Water and Sanitation systems 11, 490, 2012 [In Polish].

58. LICZNAR P., ŁOMOTOWSKI J., ROJEK M. Measurements and datas processing of precipitation for the design and exploitation of drainage systems. FUTURA, Poznań. 2005 [In Polish].

59. ARNBJERG-NIELSEN K. Quantification of climate change effects on extreme precipitation used for high resolution hydrologic design. Urban Water J. 9 (2), 57, 2012.

60. KUNDZEWICZ Z.W., KANAE S., SENEVIRATNE S.I., HANDMER J., NICHOLLS N., PEDUZZI P., MECHLER R., BOUWERL. M., ARNELL N., MACH K., MUIRWOOD R., BRAKENRIDGE G.R., KRON W., BENITO G., HONDA Y., TAKAHASHI K., SHERSTYUKOV B. Flood risk and climate change: global and regional perspectives. Hydrolog. Sci. J. 59 (1), 1, 2014.

61. ASSOCIATED PROGRAMME ON FLOOD MANAGEMENT. Technical Document No. 14, Flood Management Tools Series, WMO, 2009.

62. MARK O., PLUDAN B. Climate change and urban water systems. In: Handbook of Hydrology. Modelling, Climate Change and Variability. Eslamian, S. ed. CRC Press, London, 87, 2014.

63. TWARDOSZ R. The Synoptic and Probability Aspects of Diurnal Precipitation Variation in Cracow (18862002), Institute of Geography and Spatial Management of Jagiellonian University, Cracow 2005.

64. TWARDOSZ R., NIEDŹWIEDŹ T., ŁUPIKASZA E. Hail Thunderstorms in Kraków and their Circulation Determinants (1863-2008). In: Water in Geographic Studies, Ciupa, T., Suligowski, R. eds., University of Kielce, Kielce. 2010 [In Polish].

65. TWARDOSZ R., NIEDŹWIEDŹ T., Influence of synoptic situations on the precipitation in Cracow (Poland). Int. J. Climatol. 21, 467, 2001. 